\title{
US-Japan Trade Friction and its Dilemmas for US Policy
}

\author{
Marcus Noland
}

Working Paper No. 78

\author{
Marcus Noland \\ Council of Economic Advisors \\ Old Executive Office Building \\ Washington, D.C. 20500 \\ (202) 395-3310 \\ FAX (202) 395-6947
}

This paper draws heavily on Reconcilable Differences? by C. Fred Bergsten and Marcus Noland. I am grateful to participants of the Japan Economic Seminar for helpful comments on an earlier version of this paper. The views expressed herein are purely the author's and should not be interpreted to reflect any official position of the Council of Economic Advisors or the United States Government.

Working Paper Series

Center on Japanese Economy and Business

Graduate School of Business

Columbia University

November 1993 


\title{
US-JAPAN TRADE FRICTION AND ITS DILEMMAS FOR US POLICY
}

\author{
Marcus Noland \\ Council of Economic Advisers \\ Old Executive Office Building \\ Washington, DC 20500 \\ (202)-395-3310 \\ (202)-395-6947 (fax)
}

This paper draws heavily on Reconcilable Differences? by C. Fred Bergsten and Marcus Noland. I am grateful to participants of the Japan Economic Seminar for helpful comments on an earlier version of this paper. The views expressed herein are purely the author's and should not be interpreted to reflect any official position of the Council of Economic Advisers or the United States Government. 


\section{INTRODUCTION}

Trade frictions between the United States and Japan go back well over a century. While the form and substance of these problems have changed significantly since the time of Commodore Perry, the size and technological dynamism of the contemporary Japanese economy present US policymakers with a unique set of challenges. Bergsten and Noland (1993) group these challenges into four categories: microeconomic, structural, macroeconomic, and systemic. The focus of this paper is on the policy problems posed by the microeconomic and structural differences in the two economies, both because these are the most controversial intellectually and well and the most sensitive politically, at least in the United States. Moreover, this paper is exclusively on the Japan-related aspects of these problems, for reasons of both brevity and the presumed interests of the audience of this volume. This is certainly not to say that policies and practices in Japan are the source of all of the problems in the bilateral relationship: a persuasive case can probably be made that much of the tension in the bilateral relationship stems from anxiety in the US over declining competitiveness which is largely a domestic issue. Nonetheless, this paper focuses on Japan-related concerns. The structure of the paper is to first examine the issue of Japanese uniqueness (which provides the justification for a Japan-specific policy), then evaluates the significance of this issue for the US economy. The paper then moves toward a more normative analysis, examining possible alternative policy approaches, and concludes with a discussion of current US policy toward Japan.

\section{EVIDENCE OF DISTINCTIVENESS}

By a variety of measures, Japan has a distinctive trade pattern. Japan has an unusually low share of manufactured imports in domestic consumption, an unusually low share of intraindustry trade, an unusually small share of domestic sales accounted for by foreign-owned 
firms, and an unusually high share of intrafirm trade, which is predominantly controlled by Japanese firms. As the line of table 1 makes clear, relatively few manufactured imports make it into the Japanese market. The share of imports in Japanese consumption of manufactures is less than half that in other major industrial countries. Moreover, unlike in the other countries, which have experienced considerable increases in this import penetration ratio, the Japanese imported manufactures share has remained essentially flat, never rising above 6 percent since at least 1975 (cf. Balassa and Noland 1988, table 3.2; Dornbusch 1992, table 8; Advisory Committee for Trade Policy and Negotiations 1993). The interpretation of these raw statistics is problematic: it is unclear whether the low level of imports in domestic manufactures consumption reflects protection or the comparative advantage of a capital-abundant country with few natural resources, far from other developed countries.

Another interesting aspect of the Japanese trade pattern, identified by a number of researchers (e.g., Scott 1987, Lawrence 1987, Balassa and Noland 1988, Lincoln 1990, Noland 1990a), is the relatively low level of intraindustry trade. The term "intraindustry trade" refers to the two-way trade in differentiated manufactures within a given industry. This trade tends to increase as economies develop and the demands of firms and consumers become more complex, so that no individual firm is able to produce a sufficiently broad range of products to satisfy all demands. (An example of intraindustry trade would be cross-border trade in different makes and models of automobiles.) Intraindustry trade is sometimes argued to be of particular importance because the adjustment costs associated with an expansion of intraindustry trade are thought to be lower than that associated with a comparable expansion of interindustry trade.

As shown in table 1, Japan's intraindustry trade appears to be somewhat lower than that 
of comparable industrial countries. One interpretation (figuring most prominently in Lincoln 1990) is that this relatively low level of intraindustry trade in manufactures reflects a relatively closed Japanese market. According to this view, once Japanese firms begin producing a good, competing imports are excluded from the market either through public policies or through private arrangements. While this certainly may be the case, analytically it is difficult to determine if the observed low degree of intraindustry penetration reflects the exclusion of imports or the hypercompetitiveness of the domestic industry.

The Japanese trade pattern appears distinctive in at least two other dimensions. The first is the unusually high share of intrafirm trade. Intrafirm trade is important both as a major channel of trade and because of the suspicions that intracorporate transactions are less governed by the normal price/cost determinants than arm's length transactions are. ${ }^{1}$

The issue is of considerable interest with regard to Japan because of Japan's unusual pattern of intrafirm trade. For most countries, intrafirm trade is dominated by the intrafirm

${ }^{1}$ Concern has also been expressed over the transfer of technology through intrafirm trade. In particular, it has been alleged that Japanese firms are acquiring technology through their acquisition of US firms. The data on royalties and license fees should be regarded with a considerable degree of skepticism since tax and other considerations may strongly influence how firms price these transactions. For what they are worth, the existing data (Department of Commerce, 1993) indicate that the US-based manufacturing affiliates of Japanese parents have consistently been net importers of technology, with net payments of \$153 million in 1991. Service affiliates were net exporters of technology in 1991, with $\$ 5$ million in net revenues. Altogether, transactions between Japanese parents and their affiliates account for less than 10 percent of the royalties and license payments between foreign parents and US-based affiliates. In other words, intrafirm trade between Japanese parents and US affiliates does not appear to be a major avenue of technology transfer, and to the extent that technology transfer has occurred, the predominant direction has been from Japan to the US. 
shipments by parent firms to their foreign affiliates. This means that exports from domestic parents to their foreign affiliates exceed the exports generated by the domestically based affiliates of foreign firms back to the foreign parent. The reverse holds for imports. Japan is unusual in that Japanese parents dominate both export and import trade (Lawrence, 1991a; Encarnation 1992). Lawrence (1991a) attributes this to the prominent role of giant trading companies in Japanese trade, and he argues that this pattern of trade is consistent with imperfectly competitive Japanese domestic markets.

Table 2 reports data on US bilateral trade with Europe and Japan. In the case of Europe, US parents account for just under 30 percent of US exports to Europe, while the US-based affiliates of European firms account for around 10 percent of US exports to Europe. In the case of imports, this ordering is reversed: shipments from European parents to their US affiliates account for nearly 40 percent of imports, while imports by US parents from their European affiliates account for 10-15 percent of imports.

The second panel of Table 2 reports data on Japan. Two things are immediately obvious. First, intrafirm trade is a more important part of US-Japan trade than US-Europe trade, and second, trade in both directions is dominated by Japanese firms.

In contrast to the European case, US exports to Japan are dominated by shipments from US-based affiliates of Japanese firms back to parents in Japan, accounting for 46.9 percent of all US exports to Japan in 1990. (Although quite high, this figure has actually declined from 58.4 percent in 1986.) Exports by US parents to their Japanese affiliates accounted for only 1520 percent, depending on the definition of affiliate used, though this still represents a substantial increase over the figure in 1986. 
In the case of imports, virtually all US imports from Japan are intrafirm, with shipments from Japanese parents to their US affiliates accounting for more than 80 percent of US imports from Japan. This may be a bit misleading as more than a third of this is accounted for by wholesale trade in automobiles and parts.

It is possible that the unusual pattern and prominence of intrafirm trade between the US and Japan is due to the commodity composition of that trade. That is to say, Japan specializes in products characterized by intensive intrafirm trade, so that the high observed levels of intrafirm trade are a product of trade composition, not unusual Japanese behavior. This proposition was investigated by calculating intrafirm trade shares excluding Japan using disaggregated data, then weighing these figures by the Japanese commodity composition of trade. This calculation indicates that if Japan's intensity of intrafirm trade was the same as Europe's, the US-based affiliates of Japanese firms would account for 32 percent of US exports to Japan (in contrast to the 46.9 percent actually observed), while exports from Japanese parents to their US affiliates would account for 33 percent of US imports (instead of 81.6 percent).

The flip side of this phenomenon, reported in the final line of table 1 , is that foreign firms account for a minuscule fraction of sales in the Japanese market. This reflects the low level of imports, the predominant control of those imports that do enter by Japanese firms, and the low level of inward foreign direct investment.

These distinctive characteristics do not prove that the Japanese market is completely closed to foreigners or their goods. Indeed, a number of US firms such as Schick (safety razors), Coca-Cola Japan (soft drinks), and Johnson \& Johnson (adhesive bandages) dominate their markets in Japan (Morgan and Morgan 1991, table 6.1). Nevertheless, the aggregate figures do 
establish that the role of foreigners and foreign-made goods is unusually low in the Japanese economy.

\section{EXPLANATIONS OF DISTINCTIVENESS}

Explanations of this apparent distinctiveness can be gathered into two broad groups, one emphasizing direct trade and industrial policy interventions and the other, structural characteristics of the economy. As for the former group of explanations, domestic support policies in Japan have included direct subsidies, preferential tax treatment, preferential access to credit, government procurement preferences, establishment of producer cartels, and public subsidization of research and development (R\&D) consortia. External policies have included trade protection, restrictions on inward foreign direct investment, and control over hightechnology trade. These policies contain both domestic and trade components and have been applied to both emerging infant industries and declining senescent ones.

Serious analyses of Japanese industrial policies indicate that in total these policies have probably been welfare-reducing: on balance, they shifted resources from high- to lowproductivity uses, and have not been targeted sufficiently narrowly within the manufacturing sector to capture rents effectively. Japan's industrial support policies could thus be regarded as compensation for the negative net transfer from the Japanese manufacturing sector (cf. Krugman 1987, Lee 1989, and Noland 1993).

For its part, Japan, like many other countries in the immediate postwar period, operated a tightly controlled import trade regime justified as a response to severe balance of payments constraints. The main policy tool for controlling imports was foreign exchange allocations, but the government also maintained high tariffs and extensive systems of quotas and import 
licensing. The government supported producers in preferred sectors with subsidized loans and special tax treatment.

In 1955, with the support of the United States, Japan became a contracting party to the GATT and began a gradual period of import liberalization. Most quotas in the manufacturing sector had been eliminated by the beginning of the Kennedy Round of GATT trade negotiations in 1964, but manufactures tariffs remained high by European or American standards and involved considerable escalation by degree of processing. ${ }^{2}$

This tendency toward gradual relaxation of border measures in manufactures continued through the 1970s and 1980s, so that by the mid-1980s tariff levels in Japan were comparable to (if not somewhat lower than) those maintained by the United States and the European Community, and quotas had been largely eliminated. ${ }^{3}$ As of 1989 , the applied simple average tariff rate for industrial products (excluding petroleum) was 5.3 percent, and the weighted average 1.9 percent (GATT 1990).

The existence of nontariff barriers in Japan is indisputable: data compiled by Leamer (1990) for 1983 (the only year for which data are available) show that a simple average of 46.7 percent, or a trade-weighted average of 61.7 percent, of US exports to Japan encountered some

${ }^{2}$ See Komiya and Itoh (1988) for further discussion.

3 There were, and continue to be, a few exceptions, however. High tariffs on semiconductors, computers, and numerically controlled machine tools (which were classified as computers) were maintained until 1979, when they were reduced as part of the Tokyo Round agreement. Quotas on leather and leather footwear products were converted to a tariff-quota scheme in 1986, and since then imports have grown rapidly. Orderly marketing agreements have been negotiated covering raw silk, and a prior confirmation system exists for the importation of silk fabrics. In 1989, a voluntary export restraint was negotiated with Korean knitwear producers, which expired in 1991, and in 1993, Japan imposed its first antidumping duties, against Chinese producers of ferro-silicon manganese, a steelmaking material. 
form of nontariff barrier, indicating that not only are these barriers ubiquitous, but they are erected disproportionately in sectors of US specialization. ${ }^{4}$ What is controversial is their significance.

\section{STRUCTURAL DIFFERENCES}

In Japan there is scant evidence of significant tariffs or quotas outside of agriculture. ${ }^{5}$ Nevertheless, it is widely believed that the Japanese market is effectively closed to manufactured imports. Structural barriers alleged to deter imports include the reliance on bureaucratic control to ensure product safety; domestic cartels, discriminatory networks of affiliated firms (keiretsu), and weak competition policies; lack of intellectual property protection; government procurement procedures that advantage domestic suppliers; and restrictions on the distribution channels for imported products, to name a few. ${ }^{6}$

${ }^{4}$ Conversely, a simple average of 9.9 percent, or a trade-weighted average of 34.9 percent, of Japanese exports to the United States in 1983 (when the auto VER was binding) encountered nontariff barriers, indicating that Japanese exports also disproportionately face such barriers in the US market. These nontariff barrier data were originally collected by the United Nations Conference on Trade and Development (UNCTAD). See Laird and Yeats (1990) for a description of the UNCTAD methodology. See Lawrence (1992) for a very useful survey of the issues covered in this section.

${ }^{5}$ Indeed, the Japanese government has undertaken a number of policies to increase the amounts of imports in Japan. These have included the establishment of special import promotion areas, more-generous public financial institution support for the importation of manufactured goods, tax breaks for the importation of manufactured goods, administrative guidance, and supplementary budget allocations earmarked for imports.

In addition, a proposal was floated, but never acted upon, to use the consumption tax rebate on exports (more than $\$ 1$ trillion) to promote imports.

${ }^{6}$ Well-known anecdotes provide grist for the mill. In one case, a plan to import gasoline came to naught when government officials successfully pressured the prospective importer's bank to withdraw financing. In another case, small fiberglass boats were kept out of the Japanese market by subjecting them to inappropriate testing procedures designed for concrete boats (such as dropping them). Standards introduced for ski equipment, purportedly to fit the "unique" Japanese snow, excluded foreign-made equipment and foreign manufacturers who were not 
Moreover, close examination of individual industry case studies indicates that these regulatory barriers tend to emerge in industries where domestic producer lobbies are strong: either primary-product sectors where there are well-established producer lobbies, or highly concentrated or cartelized manufacturing and service sectors where the small number of producer firms facilitates the organization of industry lobbies. This confluence of public and private barriers inhibits entry by newcomers, whether foreign or domestic.

In Japan, where product liability law is very weak, product safety is ensured through a bureaucratic standards, testing, and certification system. ${ }^{7}$ In practice that system is susceptible to capture by producer interests and can act as a nontariff barrier to trade. Numerous cases exist in which Japanese standards were written or changed to exclude imported products, often after imports had begun to significantly penetrate the market, or in which foreign producers

apprised of the standard-setting process, although at the time they supplied about half of the skis sold in Japan. Particularly intriguing was the long-standing Japanese customs practice (now discontinued) of slicing Dutch tulip bulbs in half to check for insects. In the words of Jagdish Bhagwati $(1988,69)$, once the bulbs were severed, "even Japanese ingenuity could not put them together again." For additional examples and documentation, see Balassa and Noland (1988) and Lincoln (1990).

${ }^{7}$ Japan deliberately uses bureaucratic control as a substitute for the tort system. Plaintiffs must not only prove that a product was defective and caused injury, but that the manufacturer was negligent. As a consequence of this stiff burden of proof, and the relative lack of access to legal counsel for redress, product liability suits in Japan are rare: a recent survey of 194 big Japanese manufacturers found that only 24 had ever faced a product liability suit in Japan, and only 7 had lost (The Economist, 18 July 1992). Japanese citizens have far less access to the legal system generally than their counterparts in other developed countries. The incidence of lawyers to the general population in 1 per 8,569 in Japan, compared with 1 per 1,286 in Germany and 1 per 356 in the United States. In addition, Japan does not have a contingency fee system, so that plaintiffs must pay considerable advance fees. Moreover, the courts are understaffed to the point that the average civil case takes more than two years to resolve; complicated cases can take far longer. 
encountered extreme difficulty in obtaining certification (Balassa and Noland 1988). ${ }^{8}$

The standards, testing, and certification barriers just described are often encountered in concentrated or cartelized industries. Industrial structure issues are further complicated by the existence of keiretsu. ${ }^{9}$ These networks of affiliated firms typically have long-standing financial, managerial, and product market interlinkages. A keiretsu might consist of a group of large core firms horizontally linked across markets, together with their vertically linked input suppliers, and possibly a captive distribution network. ${ }^{10}$

Keiretsu are inherently exclusionary. Firms within the group receive preference over those outside. This discrimination may apply equally to foreign and domestic firms outside the group. There are two salient issues. First, do the possible efficiency gains through better information exchange, coordination, and monitoring outweigh the implicit costs of maintaining

${ }^{8}$ Recently, however, an unusual coalition of foreign firms and trade ministries, some domestic firms, the Japan Federation of Bar Associations, the nascent consumer and "green" movements, and some political parties have been calling on the government to revise the product liability law. Japan's Economic Planning Agency has coordinated a review of the system and has released a report recommending that Japan move to a product liability system more similar to the European Community's. Like that in the United States, the EC system does not require proof of negligence on the part of producers. Unlike the US system, however, the EC system does not permit decision by jury or punitive damages. It is hoped that movement toward a strengthened product liability law would permit the dismantling of those parts of the regulatory structure that at times act as a nontariff barrier.

${ }^{9}$ See Aoki (1987 and 1991) and Gerlach (1989 and 1992) for descriptions of the keiretsu.

${ }^{10}$ For example, the Mitsui keiretsu consists of 24 major companies: Mitsui Bank (the group's main bank), Mitsui Trust (also a bank), Mitsui Life (insurance), Taisho F\&M (insurance), Mitsui Bussan (a trading company), Mitsukoshi (a retailer), Mitsui Construction, Sanki Engineering, Mitsui Real Estate, Toray (textiles), Mitsui Toatsu (chemicals), Mitsui Petroleum, Mitsui Mining, Hokkaido Coal, Onoda Cement, Oji Paper, Japan Steel Works, Mitsui M\&M (nonferrous metals), Toyota Motors, Mitsui Shipbuilding, Toshiba (electronics), Mitsui OSK (shipping), Mitsui Warehouse, and Nippon Flour. Cross-shareholding accounts for more than half of all the shares of these firms, and the main bank finances around one-fifth of all their borrowing (Gerlach 1989). 
in-group preferences? Second, even if keiretsu are on balance efficiency-enhancing, how can this system, developed under what were essentially closed-economy conditions, be broadened to include non-Japanese firms, and made both more politically palatable and even more economically efficient?

Analyses of the keiretsu have sometimes distinguished three roles. First are the financial links. It is sometimes argued that the cross-holding of shares among keiretsu firms, in contrast to the more open "Anglo-American" stock market model, allows managers to adopt longer time horizons because of reduced fear of takeover. At the same time, the heavier reliance on mainbank loan finance and the pattern of cross-shareholding better facilitates monitoring of management decisions than would more diffuse ownership. The effects of keiretsu in the financial sphere are discussed in the section on foreign direct investment below.

It is claimed that the vertical integration of major firms and component suppliers through keiretsu relationships may also be efficiency-enhancing. ${ }^{11}$ Product development is enhanced by firms' greater willingness to exchange information in the context of a long-standing relationship. It has been argued that the vertically organized keiretsu are an efficient halfway house between complete vertical integration within a single firm (with its attendant costs) on the one hand, and arm's-length transactions on the other, by balancing reliability and control against some degree of competition among suppliers. ${ }^{12}$

${ }^{11}$ Torii and Caves (1992), for example, find that the extent of subcontracting is a robust explanator of increased industrial efficiency in Japan.

${ }^{12}$ For example, American automobile producers reportedly source around 50 percent of their parts internally, while for Japanese automakers the figure is around 25 percent (Womack et al. 1990). 
A third aspect of the keiretsu is their distribution function: many of the major Japanese consumer-goods producers have captive distribution networks, sustained by vertical foreclosure practices that would be illegal in much of the rest of the world. ${ }^{13}$ Sophisticated econometric research by Ariga et al. (1991) points to administered prices in sectors where there are strong vertical relationships or keiretsu, suggesting that control of the distribution system acts as an effective barrier to entry.

This problem is worsened by the preponderance of small, poorly capitalized stores in the Japanese retail system. The relative weakness of the retailers increases both the discriminatory impact of government regulations and the likelihood of capture by large manufacturers. ${ }^{14}$ The numerous small shopkeepers also act as the primary domestic pressure group to maintain regulations that impede the establishment of large retail stores. Indeed, the lack of access to the Japanese market by large US specialty retailers has been one aspect of the bilateral trade dispute.

Not surprisingly, competition policy has become a major issue in bilateral relations between the United States and Japan, leading to action by both governments. Under US pressure as part of the Structural Impediments Initiative (SII) talks, Japan began a process of strengthening its competition laws and their enforcement in $1990 .{ }^{15}$

${ }^{13}$ See Flath (1989) for a description of vertical restraints in Japan.

${ }^{14}$ Of related interest are papers by Sato (1990), Ito and Maruyama (1991), Itoh (1991), and Nishimura (1991), which examine the efficiency of the Japanese distribution system. Cheng (1993) develops a theoretical model to show how inefficiency in the distribution system could give rise to higher consumer prices of an exportable good at home than abroad, and nonequivalence of distribution costs and tariffs.

15 The Japan Fair Trade Commission drafted guidelines on anticompetitive practices, especially in the distribution system, clarifying which practices are illegal and therefore subject to criminal sanctions and levies. The commission also issued new guidelines restricting the use of cross-ownership of stock as a condition of doing business or as a means of limiting third-party 
The result has been a significant increase in the number of antitrust actions in Japan, although the degree of activity remains well below that observed in the United States. New guidelines were issued in some industries, and investigations were launched in others, including the financial, automobile, auto parts, paper products, and glass industries. Punitive surcharges have been running significantly higher than in the past, criminal charges were brought against firms in 1991 and 1993 (after only a single case in the preceding 17 years), and for the first time criminal charges were brought in a bid-rigging case. ${ }^{16}$ (Ironically, some of the firms involved in these cases were the Japanese subsidiaries of US firms.) The US government has expressed satisfaction that reforms of the Large Scale Retail Store Law, which was alleged to have hindered both the importation of goods and the entrance of foreign retailers into the Japanese market, are being implemented.

transactions. New rules also forbid a firm with more than 25 percent market share of a product from becoming the sole distributor of a similar imported product. Penalties have also been increased: the surcharge that can be levied on firms for engaging in illegal cartels was raised from 2 percent of sales to 6 percent (the United States had originally requested 10 percent); this surcharge is the chief financial deterrent to illegal cartelization. The maximum criminal fine was raised from $¥ 5$ million to $¥ 100$ million, an impressive increase, but still far below comparable limits in the United States or the European Community. (A Japan Fair Trade Commission Advisory Council had recommended a higher ceiling on corporations, but this was opposed by business interests and politicians. The council had also recommended raising the ceiling on criminal fines for individuals, but this was left unchanged. These recommendations were of debatable importance in any event: in only one case up until that time had criminal penalties been imposed during the postwar period.) The budget of the Fair Trade Commission was expanded, and the number of investigators was raised considerably, although the agency is still far smaller than its US counterparts (the Federal Trade Commission and the Department of Justice's Antitrust Division).

${ }^{16}$ The Fair Trade Commission angered the public, however, when it declined to press criminal charges in a Saitama prefecture dango, or construction bid-rigging case, which reportedly involved 66 construction firms (including Taisei, Japan's largest) and as much as $\$ 700$ million in public contracts. 
Action has also been attempted in the United States. In April 1992, the US Justice Department announced that it would revive the rarely used policy of applying US antitrust laws extraterritorially. This decision was widely criticized in Japan and elsewhere for its unilateral nature. Foreign governments could retaliate, either by adopting a similar stance or by enacting "blocking statutes" that prohibit or restrict firms from complying with US court rulings, as several did during earlier episodes of this type. Indeed, internal opposition within the Bush administration, and a Japanese threat to block, effectively killed the Bush administration proposal. ${ }^{17}$

Another explanation for the small role of manufactured imports in the Japanese economy is that restrictions on foreign direct investment (FDI), both historical legal restrictions and private impediments in the form of oligopolies and the keiretsu, have impeded manufactured imports, especially of complex capital goods. For most of the postwar period, the Japanese government discouraged inward FDI. In the early postwar years, this was accomplished mainly through restrictions on converting domestic profits to foreign exchange for repatriation; later an

${ }^{17}$ It would be preferable to reach multilateral (or even bilateral) agreement on competition policy. The United States already has a comity agreement with the European Community that facilitates cooperation between their competition policy authorities. The United States also has had success in prosecuting Japanese firms for bid rigging in contracts for services to US military bases in Japan. In one such case, the Justice Department reached an out-of-court settlement with 99 Japanese construction firms for bid rigging at the Yokosuka Naval Base; the firms agreed to pay fines of $\$ 32.4$ million, or 24 percent of the billed costs. In another case involving bid rigging at the Yokota Air Force Base, 11 Japanese electronics firms agreed to pay $\$ 36.7$ million in fines, or nearly 36 percent of the value of the $\$ 103$ million in contracts. Although these cases represent victories for US antitrust authorities, it would be desirable to more fully internationalize Japanese competition policy through either bilateral agreements or a broader agreement involving the European Community and perhaps other OECD countries as well. 
extremely restrictive approval system for FDI served the same purpose. ${ }^{18}$

In 1967, Japan began liberalizing its investment regime, and in 1980 the remaining legal obstacles were removed. Nonetheless, foreign firms continue to play an extraordinarily minor role in the Japanese economy (table 1). Strikingly, whereas in bilateral comparisons US and Japanese multinational firms exhibit similar behavior in third-country markets, their positions in each other's markets are very different (Bergsten and Noland, 1993, table 3.4). Even though the US firms' global stock of foreign investment is larger than Japanese firms', their stake in the Japanese market is only a quarter that of Japanese firms in the United States, according to US data; Japanese MOF data show the US firms' relative share to be even smaller (Bergsten and Noland, 1993). ${ }^{19}$

${ }^{18}$ Mason (1992) likens Japanese policy at this time to a "screen door," designed to encourage inward technology transfer while discouraging inward FDI. Borrus et al. $(1986,96)$ similarly describe the government's role as that of a doorkeeper, "determining under what conditions capital, technology, and manufactured products enter and leave Japan."

Put in another way, the Japanese government has used its various policy levers to bargain with foreigners from a monopsonist's standpoint. Goto and Wakasugi $(1988,190)$ provide the example of royalty payments on the importation of a particular Austrian steel production technology: these payments were "held down to 1 cent per ton for Japan through an agreement between MITI [the Japanese Ministry of International Trade and Industry] and the industry, while the U.S. firms paid up to 35 cents per ton for the import of the same technology." What is common in the cases of steel, numerically controlled machine tools, microelectronics, and now possibly aircraft is a pattern of selective protection, strict regulation of inward FDI and technology transfer, and preferential tax treatment and access to capital until the industry has achieved international competitiveness. Rosovsky (1985) has called this pattern "the denial of the profits of innovation."

${ }^{19}$ Foreign direct investment through merger, or acquisition of existing firms, is limited by the extensive cross-holding of shares through the main bank and keiretsu systems. A market for corporate control does not exist in Japan in the same way it does in the US. An alternative to investment through merger and acquisition would be through the establishment of new greenfield operations. In a 1991 survey of US firms operating in Japan, conducted for the American Chamber of Commerce in Japan by the consulting firm A. T. Kearney, respondents cited the high cost of doing business in Japan (largely high land costs), difficulties in locating and hiring 
There is some evidence that this situation is easing. With the collapse of the Japanese bubble economy, the number of takeovers of Japanese firms by foreigners increased dramatically in 1992, although this was from a low base and remained far below the number of Japanese takeovers of foreign firms that same year (Bergsten and Noland, 1993, table 3.5).

Indeed, in the American Chamber of Commerce in Japan survey most respondents thought that the climate for trade and investment in Japan was improving. A bare majority (52 percent) indicated that the current climate was favorable or somewhat favorable, while 18 percent thought that it was unfavorable. Fifty-five percent of the respondents thought that the investment climate had improved in the previous five years, while 40 percent saw no change, and 5 percent sensed deterioration. Two-thirds of the respondents expected continued improvement in the trade and investment climate over the next five years. ${ }^{20}$

qualified personnel, general complexities in doing business in Japan, multitiered distribution systems, exclusionary business practices by the keiretsu, and bureaucratic practices that discriminate against foreign firms as the main barriers to investment. The respondents indicated that some problems on the US side--management short-termism, inability or unwillingness to modify products for the Japanese market, and quality problems--also impeded the US presence in Japan.

${ }^{20}$ The improvement in the investment climate may be in part due to policies of the Japanese government. The government has expanded public financial institution lending and loan guarantees for inward FDI and has introduced tax incentives for foreign investors. (Subsidiaries of US firms receiving Japan Development Bank loans have included Mead Paperboard Japan KK, GE Plastics Japan Ltd., Corning Japan KK, LSI Logic KK, Procter \& Gamble Far East Inc., Applied Materials Japan Inc., and AMP (Japan) Ltd. The new tax law permits foreign affiliates to carry forward losses in the first three years to be set off against taxable income for seven years--two years longer than the carryforward period allowed to Japanese companies.) MITI has established an organization to offer consulting services to firms investing in Japan. The Japan Federation of Economic Organizations (Keidanren), the most influential business lobby, fearing an increase in investment-related tensions, has called for the government to go further and expand the scope of tax breaks and public financial institution loans for inward FDI. The Keidanren has also proposed the liberalization of legal services to facilitate inward FDI. 
Ultimately, this issue is of considerable economic and political importance. The fact that foreign firms have a relatively small presence in the Japanese market means that there is relatively weak political pressure in the home countries of multinationals to moderate their governments' policies toward Japan. Japan, in essence, holds few hostages. The development of a more symmetrical set of interdependencies would undoubtedly temper economic conflict between Japan and other countries.

An alternative means of entering a foreign market, besides exporting or investing in subsidiaries, is to license or lease firm-specific assets to producers in that market. This strategy is contingent on the existence of an enforceable system of intellectual property rights. Intellectual property consists of valuable but intangible assets such as inventions, technology, technical information, brand names, identifying symbols, and distinctive styling of products. Property rights to these assets are usually protected by exclusive and enforceable patents, design registrations, trademarks and service marks, copyright laws, and trade secret laws.

Intellectual property rights disputes between the United States and Japan fall into two interrelated categories. In the first category are disputes arising from systemic differences in the two countries' intellectual property regimes. ${ }^{21}$ The second category of disputes stem from

\footnotetext{
${ }^{21}$ The United States has a "first-to-invent"' patent system. This system is centered on the notion that the economy as a whole benefits from protecting the property rights of innovative entrepreneurial inventors. Patents are granted on the basis of which claimant is first to invent (rather than first to file an application), and technical information supporting the patent application is guarded closely during review. Foreigners have complained that the evidentiary rules effectively discriminate against foreign inventors (MITI 1993).

In contrast, Japan (along with nearly every other country in the world) has a "first-tofile" system. Under these rules, the patent is awarded to the applicant who files first, regardless of who actually made the innovative discovery. This system is alleged to give an advantage to large firms, which can more easily routinize and finance the patent application procedure. Unlike under the "first-to-invent" system, information on the application is more readily available, and
} 
simple conflicts over property rights, driven by technological rivalry.

Japan's intellectual property rules have been widely criticized and were taken up in the context of the SII negotiations. The major complaint of foreign firms is that the Japanese implementation of its "first-to-file" system is inadequate. The average time required for a patent to be granted is five to six years, with some applications taking a decade or more. (In the United States the average time is 19 months.) Reasons for the long delays include too few inspectors, the practice of allowing firms to file oppositions to the patent before it is granted, and the requirement that applications be filed in Japanese (but with later correction of translation errors not permitted). ${ }^{22}$ As a result of the protracted process, Japanese firms can gain access to information on foreign technological developments before foreign firms have been able to secure their property rights. Moreover, since protection is granted from the date of filing, the delays can substantially erode the period of exclusivity that the innovating firm eventually enjoys. ${ }^{23}$

indeed, one can argue that the system is essentially designed to accelerate the diffusion of technological advance throughout the economy.

22 The United States has 1,500 patent office officials, who handle 150,000 annual applications; the European Community has 1,300 officials to handle 50,000 applications; Japan, meanwhile, has fewer than 1,000 officials, who attempt to process 720,000 applications yearly. Japan is virtually alone among developed countries in allowing pregrant challenges to patents; the European Community discontinued this process because it was being abused by firms to delay the issuance of patents to rivals.

${ }^{23}$ In one case, it took Corning Glass Works (now Corning Inc.) nearly a decade to obtain a fiber optics patent. In the meantime, Japanese rivals developed competing products. Corning sued, and Sumitomo Electric eventually paid the US firm $\$ 25$ million in an out-of-court settlement.

The most celebrated case, however, is the Texas Instruments Inc. (TI) Kilby '275 patent for the integrated circuit. TI applied in Japan for the patent in 1960, but it was not granted until 1989--nearly three decades later! TI subsequently engaged nearly 30 firms in negotiations over licensing and royalty fees, which are estimated to now bring the company $\$ 250$ million annually. The firm is still locked in a suit with Fujitsu Ltd. over whether to interpret the Kilby '275 patent narrowly or broadly. 
Trademark registration is similarly slow. In the United States, the right to a trademark belongs to the firm that first used it commercially, but in Japan, foreign trademarks may be registered by Japanese firms to preempt their subsequent introduction by the originating firm. ${ }^{24}$

As a consequence of recent reforms Japan has been moved from the list of "Special 301" intellectual property rights "priority watch countries" where it had been since 1989, to the lower-priority "watch country" list in April 1993. In light of past difficulties in obtaining intellectual property rights in a timely fashion and securing their enforcement in Japan, it remains to be seen whether these new legal rights will represent a major step forward. A key may be the changing interests of major Japanese firms: as these firms become relatively more important innovators, their own political interests will increasingly lie with strengthening intellectual property rights protection. ${ }^{25}$

\section{ASSESSMENT OF MARKET ACCESS BARRIERS}

Estimation of the impact of the mostly overt barriers to trade in primary products is relatively straightforward. Bergsten and Noland (1993) report results that indicate that complete elimination of all agricultural trade barriers in Japan might increase the incomes of US producers by the equivalent of 28 percent of exports. (This would occur both through a combination of

${ }^{24}$ Balassa and Noland (1988) give several examples of this practice. A more recent (1991) example comes from Texas, where, upon liberalization of the Japanese ice cream market, a Japanese firm tried to preemptively register the trademark of the locally beloved Blue Bell Dairy. The attempt was foiled by the high-level political intervention of then-Sen. Lloyd Bentsen (D-TX).

${ }^{25}$ It would be desirable for the United States and Japan to move closer to the European Community standard in this area. This would involve bringing the United States into conformity with the first-to-file patent system used elsewhere in the world. For Japan it would mean speeding up the patent approval process (as it pledged in the SII negotiations) and discontinuing the practice of allowing pregrant patent challenges. 
higher export volumes to Japan and through higher prices on exports to all markets.) Liberalization of Japanese fuels markets could lead to US export increases in fuels of 61 percent Bergsten and Cline, 1987), though environmental concerns about the exploitation of Alaskan oil could limit the potential impact. Comparable figures for potential gains in nonfuel minerals and services are unavailable.

What attracts the most attention, however, are the potential gains in manufactures, and here the story is far more controversial. The reason is that the essentially hidden and arbitrary nature of these trade barriers poses very difficult problems for economists trying to assess their impact. As a consequence, a veritable cottage industry of researchers has eschewed the strategy of attempting to measure the impact of these informal barriers directly, and instead has focused on inferring their impact indirectly. The usual procedure followed in this literature is to estimate econometrically a model of international trade, and then to ascribe to trade policy the differences between actual and predicted trade flows. Since this amounts to an analysis of the error terms of the regression, the robustness of the underlying estimates is of crucial significance. Perhaps not surprisingly, these studies have reached a variety of conclusions as to the importance of Japanese trade policy.

Saxonhouse $(1983,1989,1992,1993)$ has argued that the informal barriers, however vexing, are ultimately of little quantitative significance. To substantiate this position, he regresses either net or gross trade flows against cross-national data on factor endowments, excluding Japan from the sample. He finds that, in the vast majority of cases, accounting for 
nearly all of Japan's trade, Japan's actual trade flows fall within statistical forecast bounds. ${ }^{26}$ On this basis he concludes that, however unusual Japan's trade pattern, it can be explained on the basis of Japan's equally unusual factor endowments, without reference to trade policy, much less trade policy of a sub rosa sort.

These widely cited studies have been criticized on a number of grounds. First, their conclusions are at variance with what we know to be true about formal Japanese trade policies. Tests on data for 1964, for example, fail to indicate that Japan's trade pattern was distinctive (Saxonhouse 1983), yet it is a matter of historical record that Japanese border measures were unusually high prior to the Kennedy Round. In the same paper, Saxonhouse reports results for 1979 that indicate that Japan's trade pattern was not unusual in the rice sector--even though there was a complete import embargo. This inability to detect known instances of protection suggests that Saxonhouse's tests may have very low power against alternative explanations. ${ }^{27}$

Balassa and Noland (1988) suggest one reason why this might be the case. The technique used to correct for possible errors in measurement of the factor endowments (or for variations in factor quality) is valid only if errors in the measurement (or variations in factor quality) and trade policies are unrelated. If trade protection is correlated with factor intensity (as basic

${ }^{26}$ In a personal communication to the author, Saxonhouse has indicated that, according to the model used in the 1989 paper, if Japanese global imports in 1979 were as expected they would have been $\$ 7.2$ billion (or 7.2 percent) higher than they were in fact. According to the model used in the 1993 paper, Japanese global imports would have been $\$ 8.8$ billion (or 7.7 percent) higher in 1983 than they were.

27 It should be recalled, however, that the tests measure whether the trade pattern is distinctive--so that if many other nations maintained barriers of a comparable importance the regressions would not identify Japan as an outlier, even though it was highly protected in absolute terms. 
political economy would suggest), Saxonhouse's approach will attribute to measurement error precisely the effects of trade policy that one is trying to detect. So, for example, although Japan protects arable land, the Saxonhouse technique would attribute low agricultural imports to superior land quality and find no evidence of protection. ${ }^{28}$ Noland (1992a) imbedded the Saxonhouse model in a more general framework and confirmed the unreliability of the Saxonhouse approach, and using a model specification not used in Saxonhouse's papers, found some weak evidence that Japan is indeed an outlier.

Noland then regressed the residuals of this first-stage regression against policy variables to investigate whether trade policies were correlated with these deviations from the expected trade pattern. His results indicate that Japan's unusual trade behavior is indeed related to both tariff and nontariff barriers in Japan, as well as to VERs applied to Japanese exports by Japan's trade partners.

Lawrence (1991b) and Harrigan (1993a, 1993b) both examined bilateral trade in the context of models based on the assumption that countries' trade in differentiated products is proportional to their shares of world output. Lawrence concluded that Japan imports fewer manufactured goods than would be expected on the basis of the model. Using a slightly different approach, Harrigan found that using two different models that Japan in relative terms Japan imported 24-28 percent less than the US when differences in factor endowments were taken into account. He also concluded that, while Japan's manufactured imports were unusually low, so

28 In fact, results reported in Saxonhouse (1989) suggest that this method generates implausible estimates of differences in international factor quality (e.g., the productivity of capital in Great Britain is nearly 11 times the world average; Icelandic labor is more than four times as productive as the world average; education in Cyprus is more than five times the quality of the world average). 
were its exports. Bilaterally both Japan and the US were more open vis-à-vis each other than was Europe to either.

Saxonhouse (1992) analyzed bilateral net exports and obtained results somewhat similar to Harrigan's. He found that in 1985 Japan's net exports of manufactured goods to Europe were lower than expected, and Japan's net exports to the United States were $\$ 13.2$ billion higher than expected. He attributes it to trade diversion due to European barriers against Japanese exports, but this could also be due to Japanese import barriers against US exports. Noland (1992b) found that Japanese imports are unusually low in sectors in which Japan faces VERs; this could be interpreted as supporting Saxonhouse's export diversion argument. In any event, this Saxonhouse paper is subject to the same methodological criticisms elaborated earlier.

A number of studies have examined the possible impact of keiretsu on Japan's trade pattern. Kreinin (1988) surveyed the capital-goods procurement practices of the Australian subsidiaries of multinational firms. He found that the subsidiaries of Japanese firms used far less open procurement practices than did the subsidiaries of non-Japanese firms and were far more likely to purchase equipment from their home country.

Three other studies examined this question econometrically in a single-country, crossindustry framework. Petri (1991) found that import penetration was negatively related to the share of final purchases by business and government and the degree of oligopoly in distribution. If businesses and government were to achieve the same import propensity as households (controlling for differences in the composition of demand), Japanese manufactured imports would double. Lawrence (1991b) added variables relating to keiretsu affiliation to Petri's model and concluded that, while vertical keiretsu were efficiency-enhancing (reducing imports and 
promoting exports), horizontal keiretsu were not (they reduced imports only). Elimination of the keiretsu would lead to an initial increase in manufactured imports of $\$ 30$ billion (or more than 100 percent from a 1985 base), which would then be partially offset by a depreciation of the yen. Fung (1991) found that the presence of keiretsu increased Japan's trade surplus with the rest of the world in general, and the United States in particular.

The fundamental problem with these three studies is that one cannot say anything sensible about the implications of Japanese practices for world welfare by examining cross-industry trade performance from the perspective of a single country. One study, Noland (1992a), addresses this issue. First, a cross-national model of comparative advantage is estimated. The residuals from these regressions represent the component of actual trade flows that cannot be explained by factor endowments (i.e., unexplained deviations from comparative advantage). These residuals for Japan are then regressed cross-industry against trade policy and keiretsu variables. This approach provides a check on the other keiretsu studies and attempts to test the indirect inferences about trade policies made by the studies discussed above. These results broadly confirm the earlier results: keiretsu are consistently associated with higher than expected net exports and with lower than expected imports. Whether this is due to keiretsu enhancing their members' efficiency or acting as barriers to entry is not determinable. ${ }^{29}$

${ }^{29}$ These studies have been criticized on a variety of grounds. First, there is no formal definition of keiretsu, so the classifications used in these studies are somewhat arbitrary. The particular classification scheme used in all of these studies puts a heavy weight on financial linkages (main banks loans and cross-shareholding) to determine keiretsu affiliation. One could construct measures using alternative criteria which could lead to different results.

Second, they use fairly small samples (50 or fewer industries). It is also possible that the results are being driven by one or two industries with low imports and a high degree of keiretsu affiliation (e.g., automobiles). Nevertheless, the apparent consistency in these results, obtained independently by different researchers using differing models and data sets, suggest that keiretsu 
The studies just reviewed attempt to estimate the impact of public policies and private preferences on trade quantities. Another approach is to examine price evidence. Numerous surveys have found that traded-goods prices are far higher in Japan than elsewhere (Economic Planning Agency of Japan 1989; US Department of Commerce 1989, 1991; Summers and Heston 1991; Union Bank of Switzerland 1991). Sazanami et al. (1993), using import and producer unit price data from the Japanese input-output table, have calculated the "tariffequivalents" of Japanese nontariff barriers. Their results are astounding, indicating tariffequivalents of more than 500 percent in some cases.

Price differences have been also discovered in bilateral data collected in the context of the SII negotiations. The joint survey conducted by the US Department of Commerce and MITI in 1991 found that two-thirds of the products covered were on average 37 percent more expensive in Japan than in the United States; the survey done in 1989 obtained quantitatively similar results. Since unlike in the study by Sazanami et al. these data involve exact brand and model comparisons, the question immediately arises as to why arbitrage does not eliminate these price differences. The persistence of these differentials suggests that they are not simply due to short-run exchange rate misalignment, but rather that they are the product of some type of market closure. ${ }^{30}$

A variety of hypotheses have been put forward to explain this phenomenon. One is that the high retail prices of traded goods in Japan are due to high costs in the retail sector. These

have a significant impact on the Japanese trade pattern.

${ }^{30}$ A distinct line of research has investigated the pricing strategies of Japanese firms in response to exchange rate changes (e.g., Loopesko and Johnson 1987, Marston 1991). 
include the notoriously high price of land, as well as alleged inefficiencies in the distribution system (Lawrence 1991b, Ito and Maruyama 1991, Itoh 1991). Another set of explanations emphasizes conventional resistance factors to international trade such as transportation costs and trade barriers. Bergsten and Cline (1987) estimate that the aggregate tariff-equivalent of nontariff barriers of all sorts imposed on US exports to the Japanese market is on the order of 25 percent. Lastly, some researchers have argued that the high prices in Japan are due to strategic decisions by oligopolistic firms: either rent extraction by foreign exporters or Japanese importers generating high prices in Japan (Cline 1990), or exclusionary practices and dumping by members of the keiretsu, contributing to high prices at home and low prices abroad (Cheng and Kreinin 1991). Keiretsu domination of distribution channels is also alleged to contribute to the price differentials.

Noland (1992b) used the Department of Commerce-MITI survey data to test these hypotheses. The results of this paper indicate that these price differentials are associated with trade policies (in particular the presence of nontariff barriers) and the existence of keiretsu, suggesting, in confirmation of the trade quantity studies, that these are the main sources of market closure. (Indeed, these results would appear to tilt the explanation of the effect of the keiretsu on trade volumes toward the market closure hypothesis and away from the enhancedcompetitiveness hypothesis.) A conservative estimate is that elimination of these sources of market closure might lead to a more than 20 percent increase in the volume of manufactured imports into Japan. (In comparison, elimination of all formal tariff and nontariff barriers might 
lead to a 3 percent increase in manufactured import volumes. $)^{31}$

The results of this study along with six others are summarized in table 3 . It is unsurprising that the results appear to be as divergent as these are: the question that they are trying to answer is an inherently difficult one. The studies can be broken down into three groups. The first group consists of Petri (1991) and Lawrence (1991b), who generate estimates of the potential increase in Japanese manufactured imports of 54.3 to 100.0 percent. For purposes of analyzing bilateral trade, these studies have two drawbacks. First, they were derived on the basis of single-country, cross-industry regressions, and so do not take into account the characteristics of countries other than Japan. Second, they refer to global, not bilateral, trade.

The Saxonhouse papers make up the next group. These figures are not directly comparable to the others: they refer to all imports, not just manufactured imports as do the other papers. Nonetheless, these results give the impression of implying somewhat less unusual importing behavior on the part of Japan--indeed that Japan's trade is as its factor endowments predict. This does not mean that Japan is a free trader, but only that its trade is not any more distorted than the world average. Saxonhouse (1992) interprets his finding that 1985 Japanese net exports were $\$ 13.2$ billion higher than predicted as reflecting diversion of exports from Europe to the United States due to European trade restrictions. (This paper is not included in

\footnotetext{
${ }^{31}$ Applying the coefficients reported in this paper to the sample means (with the recognition that the sample may not be representative of the whole manufacturing-goods sector) yields the finding that elimination of the trade impediments would lead to a 32.5 percent fall in import prices. Noland (1989) reports a long-run price elasticity of demand for Japanese imports of 0.67. Presumably this is a lower-bound estimate for manufactured goods. Applying this elasticity to the price decline above, one obtains a 21.8 percent increase in import volume.

Alternatively, Bergsten and Cline's estimate of -1.16 for the Japanese import price elasticity of demand, applied to the price change noted above, yields an estimate of potential manufactured import growth of 37.7 percent.
} 
table 3 because it refers to net exports and is even less directly comparable to the other studies.) Putting the three papers together, one gets the impression that both Japanese imports and exports may be lower than expected. In any event, the previously detailed problems with the modeling approach used in these papers point to the unreliability of their results.

The final group of studies, by Bergsten and Cline (1987), Lawrence (1987), and Noland (1992b), generates estimates of potential increases in Japanese imports in a lower, narrower range than the Lawrence and Petri papers: 21.8 to 45.4 percent. $^{32}$ Three things should be noted about these studies. First, they are based on three different methodologies: industry-by-industry estimates in the case of Bergsten and Cline, cross-national regressions in the Lawrence study, and bilateral price regressions in the Noland study. Second, Bergsten and Cline, and Noland are based on US-Japan bilateral data. Third, some liberalization clearly occurred in Japan between 1980 and 1991; one should expect the potential manufactured import increases to decline. Using the estimates in the Bergsten and Cline, and Noland cases, this indeed occurs: the highest estimate, Lawrence's 41.3 percent, is based on data from 1980; the next highest, 34.9 percent (the midpoint of the Bergsten-Cline range), which is approximately 15 percent lower, is derived from 1985 data; and the lowest, 29.8 percent (the midpoint of Noland's range), calculated from 1991 data, is 15 percent lower still. All of this suggests that, from the standpoint of estimating current potential manufactured import increases in Japan, the greatest probability weight should be placed on the Noland (1992b) estimates.

These estimates are by their very nature imprecise: complete liberalization in Japan would

32 It should be noted that according to Goto (1990) that when the Lawrence model was reestimated with the variables expressed in levels rather than logs, that Japan was no longer unique. 
engender changes in economic behavior beyond the historical experience on which these models are based. They are interesting, nonetheless. According to the estimates reported in Bergsten and Noland (1993), if Japan were to eliminate all formal and informal barriers to trade, US exports to Japan would initially increase by somewhere in the range of $\$ 8.9$ billion to $\$ 18.2$ billion, with a central estimate of $\$ 13.6$ billion. ${ }^{33}$

Greater access is in the US economic interest. It would also contribute to reducing political tensions both by eliminating sources of sectoral trade disputes as well as by contributing to a reduction in the overall bilateral deficit. The questions are, What should the United States' strategic priorities be in pursuing greater access? And what tactics should the United States use to achieve them?

\section{STRATEGY AND TACTICS}

Certain recurrent themes emerge in the industry case studies explored by Bergsten and Noland (1993). First, the Japanese government has pursued more obvious policies of industrial development than the United States. This is not to say that the United States has no industrial policies--it clearly does--but rather that Japanese policies have had a much more narrow industrial goal, without the national security emphasis that has played a major role in US policy

${ }^{33}$ Increasing market access in Japan would have an impact on the bilateral deficit, although by how much is difficult to say. The initial increase in Japanese imports would be accompanied by increased Japanese efficiency and by a depreciation of the yen. Both would tend to both dampen the import increase, as well as encourage more Japanese exports. In the end, the bilateral deficit would shrink by something less than the full $\$ 8.9$ billion to $\$ 18.2$ billion. In reality, liberalization would occur over an extended period of time, so that the reduction in the deficit due to liberalization would be intertwined with fluctuations in the balance due to macroeconomic developments. As a consequence, it could be very difficult to disentangle the effects of liberalization even in retrospect. None of these qualifications should detract from the desirability of gaining greater access to the Japanese market, however. 
formation. Consequently, in all of the cases studied, Japanese government action has played a significant role in how competition between US and Japanese firms has been conducted.

How this competition has played out has depended in large part on the fundamental competitive strengths of industries in the two countries. As a consequence, there are basically two typologies of conflict: the first arises where demands for trade action arise from importcompeting sectors in the United States faced with a competitive Japanese industry (notably automobiles, and arguably semiconductors); the second where competitive US firms seek access to a restricted Japanese market (computers, telecommunications, securities, retailing, construction, and arguably semiconductors). While the dynamics of the first type are relatively well-known, the second type of trade conflict, arising from the access problems encountered by US firms in the Japanese market, presents US policymakers, with more difficult and subtle problems and choices. The importance of these export access disputes has risen as new measures introduced into US trade law such as Section 301, Special 301, and the late lamented Super 301, have given US exporters recourse to non-GATT remedies. The recurrent pattern that emerges from the Bergsten and Noland (1993) case studies is of competitive US firms denied access to the Japanese market by a combination of public policies and private behavior. In a number of cases, this takes the form of officially or informally sanctioned cartel behavior by Japanese oligopolists. The response of some firms is to seek US government assistance in prying open the market. (Presumably some firms, frustrated by their experiences, simply give up and are never heard from again.) If the US government takes up their case typically using the new trade laws as leverage, and sufficient pressure is applied to Japan (including overt threats of retaliation in a number of cases), possibilities for change begin to appear. 
The goals of the Japanese government (assuage foreign pressure) and Japanese business (maintain oligopoly profits) are obvious, as is the solution: buy off the foreign pressure. In practice this means allowing a particular foreign firm or firms into the domestic oligopoly and a share of cartel rents in exchange for a cessation of political pressure.

This solution, although perhaps satisfactory to the Japanese government, Japanese business, and the privileged foreign firm(s), creates a dilemma for US policymakers and those in third countries. Put starkly, should the United States be satisfied with certain of its firms gaining possibly privileged access to the Japanese market, or should it press for more fundamental liberalization to facilitate the entry of additional US and foreign firms on a competitive basis?

Although it is the structure of the Japanese economy that sets up this dilemma, it is the dynamics of US policymaking that makes the dilemma particularly vexing. The United States has a producer-oriented, complainant-initiated trade policy system. In colloquial terms, it's the squeaky wheel that gets the grease. Thus, US trade policymakers face two related problems: how to prioritize the myriad problems that they confront with Japan, and how to respond to cooptation opportunities presented by Japanese policies.

Priorities should be set on the basis of the likely payoff to the US economy and the likelihood of success. The obvious solution would be to calculate the present discounted value of prospective trade deals and prioritize them according to this ranking. One would want to take into account the stream of benefits to the US economy as well as the political costs and likelihood of successfully concluding a deal. The fact that one would regard the benefits as a stream extending into future years would tend to tilt the calculation toward rapidly growing 
markets. Focusing on the impact on the US economy (as distinct from the sales of US firms) would tend to tilt the prioritization toward activities with a large domestic component. While advocating the application of basic cost-benefit reasoning would seem singularly unoriginal, given the incentives facing US policymakers this is not necessarily so. ${ }^{34}$

To make these implications concrete, Table 4 reports potential export increases calculated by Bergsten and Noland (1993). (It should be emphasized that these cases are listed for purely illustrative purposes and are not comprehensive. $)^{35}$ By far the largest impact from liberalization has been in cigarettes, where US exports increased by $\$ 1.2$ billion, followed by beef ( $\$ 500$ million), the STA ( $\$ 415$ million as an upper bound), and citrus ( $\$ 100$ million). ${ }^{36}$ The smallest apparent gains were in fiber optics ( $\$ 33$ million). On the basis of these admittedly crude

${ }^{34}$ Recent trade deals, including the Semiconductor Trade Agreement and targets on auto parts purchases, have been specified in terms of corporate identities, not location of production. (To wit, a TI semiconductor produced in Kyushu counts as American, while a Hitachi chip produced in California counts as Japanese.) The proposed quotas on Japanese-maker automobiles, which would count the output of Japanese plants in the United States as Japanese, would extend this trend.

This is fundamentally the wrong way to go. The US government should promote the interests of its citizens, which coincide most extensively with the interests of the internationally immobile factors of production. Consequently, issues should be prioritized according to their impact on the US economy, not the worldwide sales of US firms.

This has two immediate implications. First, trade pacts should be negotiated on the basis of benefits to the US economy rather than corporate identity. Second, deals that result in exports of goods and services from the United States would therefore tend to receive higher priority than deals that would result in higher sales for US firms, but where the production of goods and services would occur abroad.

${ }^{35}$ It should also be noted that while the calculations refer to bilateral export increases, the global increase is really more relevant. As emphasized in Bergsten and Noland (1993) bilateral balances are of no economic interest per se.

${ }^{36}$ In addition to exports, the STA may have increased the sales of North American firms in the Japanese market, generating additional benefits to the US economy in the form of remitted profits and increased headquarters activities in the United States. An upper-bound estimate of the sales impact of the STA would be an increase of $\$ 1.1$ billion. A similar issue arises with regard to potential gains in computers, where a significant share of the increased sales would be sourced outside the United States. 
calculations, it would take three fiber optics cases to have the impact on the US economy that the citrus deal did, 15 fiber optics cases to equal beef, or 36 fiber optics cases to match cigarettes.

The second column in table 4 reports some potential gains in sectors yet to be liberalized. To reiterate, these are by their very nature speculative estimates and subject to large errors. They are interesting nonetheless. The largest potential gain, more than $\$ 1$ billion, comes from eliminating discriminatory public procurement practices in (nonsuper-) computers. (Again, this ignores the estimated $\$ 1$ billion in estimated sales sourced outside the United States.) This is followed by liberalization in fuels ( $\$ 789$ million) and in wood products ( $\$ 750$ million), the entry of Toys ' $R$ ' Us into the Japanese retailing market ( $\$ 150$ million), and the elimination of discriminatory public procurement practices in supercomputers ( $\$ 30$ million). The listing of Toys ' $R$ ' Us is a bit misleading, since it was part of a broader effort to get retailers into the Japanese market, and the gains to other retailers have not been quantified. Nonetheless, the differences in magnitudes are striking: it would take 25 supercomputer deals to equal the potential gains in wood products, or 36 supercomputer public procurement agreements to equal one mainframe computer public procurement accord.

These comparisons should be qualified in three ways. First, they ignore any possible spillovers or externalities in the high-technology cases. Nonetheless, these figures suggest that there would have to be some extremely large externalities to a product such as fiber optics or supercomputers to compensate for the fundamental differences in export potential. The second qualification reinforces this caveat: these figures are the direct (not total) effects. If indirect effects on the rest of the economy through interindustry linkages are taken into account, the 
natural resourcelbased products will look even better, since they presumably have a lower import content.

Third, these estimates are static. As argued above, one would want to attach a greater priority to growing markets, both because the future payoffs are expected to be larger, and because new entrants in a growing market would presumably encounter less political resistance in Japan. These considerations might tilt the calculations toward high technology, where relatively small initial payoffs in manufacturing might also be parlayed into larger gains if they helped firms penetrate the "design-in" process.

More generally, these criteria will tend to favor cases involving products exported from the United States over those where a significant share of the products and/or services are sourced outside the United States (such as semiconductors and Toys 'R' Us).

Having established some priority guidelines, the next issue is of tactics. US policymakers have essentially three options, in increasing order of difficulty in attainment: accept the entry of US firms into the Japanese oligopoly; go for a VIE, under which multiple firms (including foreign firms) can compete for market share; or aim for complete liberalization.

In sectors where there is one dominant producer (e.g., fiber optics, supercomputers), options 1 and 2 are in effect similar, and US policymakers may face overwhelming political incentives to adopt these approaches. Given the commitments of bureaucratic and political resources that attempting to achieve complete liberalization would require, satisficing with option 1 or 2 may not be a bad strategy.

As the number of US producers (or potential producers) increases, however, accepting co-optation or a VIE appears increasingly less attractive. Accepting co-optation, by pressuring 
the Japanese government until particular US firms have gained market access and then backing off, would imply a preferential disposal of rents that would be difficult to sustain politically. A VIE solution that facilitated more equitable access among competing US firms would be more acceptable politically. The question then becomes: When are VIEs preferable to traditional procedural liberalization efforts? ${ }^{37}$

A certain degree of skepticism is in order. First, VIEs are likely to be captured politically. Producer groups in the exporting country will want the covered industries defined as narrowly as possible, to eliminate intergroup competition and to assure themselves that they will reap the prospective benefits. The importing country will also want to define them as narrowly as possible, to facilitate implementation. (Remember that the importing-country government ultimately has to ensure that the targets are attained.) Thus, there is a natural coincidence of interests between domestic producer groups and foreign governments to set up a patchwork of narrow VIEs. Indeed, the Japanese would make incumbents the recipients of VIEs, essentially “taking hostages" among US firms and turning them into allies against all new entrants, domestic or foreign.

Indeed, the ability of the importing-country government to implement and enforce such an agreement will be positively related to the degree of government involvement in the industry and inversely related to the number of firms. This suggests that the simplest case in which to implement a VIE would be that of a monopsonistic public corporation such as a national telecommunications monopoly. (In this case the obvious first-best solution is to negotiate the removal of public procurement preferences.) Implementation will grow increasingly difficult as

${ }^{37}$ For welfare analyses of VIEs see Dinopoulous and Kreinin (1990). 
the number of importing firms increases. Attempts to coordinate importing behavior across firms will inevitably contribute to the cartelization of the industry. Moreover, if the Japanese firms export to and produce in the United States, the US government runs the risk of encouraging cartelization and then importing the cartel behavior into its own market.

This raises the issue of third parties. A VIE must either include or exclude third parties. If it excludes them, it may shift rents to the demandeur country at the expense of third parties, and encourage emulation by other exporting countries elsewhere. ${ }^{38}$ (Indeed, the VIE may set a precedent, and the original demandeur may find itself the object of VIE demands from others.) If instead the VIE includes third parties, it reduces one of the avenues by which cartel behavior in the demandeur's own market can be disciplined.

Second, the quantitative targets are fundamentally arbitrary. One can look at market shares in third-country markets, but these are little more than crude and debatable benchmarks. There is no consensus standard or methodology for judging what market shares ought to be, and one lesson of the sophisticated econometric literature surveyed above is that a significant amount of art as well as science is involved in these judgments. One observer's invisible barrier is another's superior competitiveness, and experience shows that market outcomes can vary greatly from the a priori estimates of knowledgeable observers; indeed, the negotiated outcomes could be far less desirable than those obtained by removing the trade barrier. ${ }^{39}$

${ }^{38}$ In the auto parts case, European and Australian officials have complained that purchases have been diverted from their exporters to US firms. Japanese officials have denied that any diversion away from third-party suppliers has occurred.

${ }^{39}$ A case in point is US cigarette exports to Japan, which faced multitudinous tariff and nontariff barriers prior to liberalization: annual US exports were $\$ 95$ million, accounting for less than 1 percent of the Japanese market. Three contemporaneous studies addressed the potential 
Moreover, there is no obvious time dimension to the VIE (should they last for a fixed period? indefinitely?), nor is there any obvious way to determine how the quantitative target should evolve over time.

This leads to the third problem, namely, that in most of the cases surveyed,credible threats of retaliation have been important in achieving action in Japan. The VIE puts the exporting country in the position of making a decision whether to retaliate on the basis of factors outside either government's control, such as changes in the composition of demand or technological innovations (as in the case of the STA) or exchange rate changes. This would inevitably erode the credibility of enforcement of these agreements.

Lastly, it is always tempting for a large country to use its inherent market power to achieve its desired ends. It is almost assuredly true, however, that the adoption of a VIE strategy by the United States will create a precedent that will be adopted by other countries and will come back to haunt its originator.

These concerns reinforce the presumption in favor of first-best solutions. In cases where there are clear instances of public impediments to imports (such as the discriminatory public

increases in foreign market shares: Saxonhouse (1983) described such potential gains as "modest"; Bergsten and Cline (1985) estimated that, with liberalization, US exports might increase by $\$ 98$ million; and the US Department of Commerce (in a study cited by Bergsten and Cline) estimated that the market might grow by $\$ 1.9$ billion. In point of fact, US exports increased 13-fold, from less than $\$ 95$ million in 1985 to more than $\$ 1.3$ billion in 1990, after the market was opened. Similar is the case of beef: contemporary observers (e.g., the Department of Commerce, and Bergsten and Cline) predicted that US exports would increase by $\$ 280$ million with liberalization. In fact, the increase in exports has been nearly twice this amount. Likewise, Bergsten and Cline, and the US Department of Commerce, predicted that citrus exports might increase by $\$ 40$ million with liberalization; exports in fact grew by more than $\$ 100$ million. In hindsight, it is very difficult to believe that trade officials could have obtained negotiated solutions in any of these cases that would have been nearly as advantageous to US interests as the market solution obtained through genuine liberalization. 
procurement cases), it would be better to negotiate the removal of the barrier. Similarly, in the cases of private entry barriers, it would be preferable to apply internationally agreed-upon competition policies, recognizing that in cases where there are only a few potential exporters, the cost-benefit calculation may indicate that the co-optation option may make sense. In the case of high-technology development programs it would be best to negotiate agreements on countervailing subsidies.

Nonetheless, VIEs do appear to be suited to a particular kind of problem that the United States sometimes faces in its dealings with Japan. Foreign providers of industrial intermediates or capital goods wanting to sell into the Japanese market (or even to the Japanese firms' subsidiaries outside of Japan) sometimes find that their entry is blocked by the contracting relationships of the vertical keiretsu system. This system may be efficiency-enhancing and may warrant emulation by non-Japanese firms, as some have already begun to do. At the same time, these long-standing relationships were developed in the context of what was essentially a closed system. Once these firms become major players in the international economic system, there is a clear political (and arguably an economic) rationale for developing a broader, more inclusive, international web of relationships.

Moreover, there may be cases, such as semiconductors and supercomputers, where the issues are such that internationally agreed-upon rules of competition are unlikely to be formulated in the politically relevant time frame. In these cases policymakers will be inevitably pushed toward the second best solutions. Once one has entered the world of second-best, evaluating the desirability of piecemeal policies becomes extremely difficult. Nevertheless, these are the choices that policymakers face in reality. 
In these cases, VIEs may make some sense as a mechanism to force the adaptation of a system that was developed in the closed, policy-distorted environment of Japan in the 1950s and 1960s. A VIE could then be considered as a temporary compensatory policy to move the Japanese system closer to a free trade equilibrium. It may act as a prod to internationalize the keiretsu. It is precisely this encouragement to bring non-Japanese firms aboard in product development and the "design-in" phase that could be the avenue by which this inherently discriminatory structure is made compatible with an open international trade system. Once the process of inclusion begins, presumably some non-Japanese firms will succeed and some fail in developing stable and productive relationships with their Japanese counterparts; this is as it should be. At the same time, Japanese firms will have a positive incentive to find capable, efficient partners.

Yet in light of the potential pitfalls of the VIE approach, one should be very cautious in advocating them. It makes no sense to propose them for consumer products or final goods of any sort. They should only be considered in the case of industrial intermediates. They would make the most sense in rapidly expanding markets where new entrants could be accommodated without displacing existing domestic production. Even then, their application should be weighed carefully against first-best alternatives.

\section{CURRENT POLICY}

Current US policy centers on the Framework negotiations between the United States and Japan which were begun in June 1993, which can regarded as the successor to the earlier Market Oriented Sector Selective (MOSS) and Structural Impediments Initiative (SII) talks. The Framework document agreed to at the time of the Tokyo summit in July 1993 calls for the two 
countries to undertake macroeconomic, sectoral and structural reforms, and cooperation in global issues of common interest such as the global environment. ${ }^{40}$ The sectoral and structural parts of the talks are organized into five baskets: government procurement, regulatory reform and competitveness, other major sectors, economic harmonization, and implementation of existing arrangements and measures. ${ }^{41}$

The Framework talks represent a departure from previous negotiations in two substantive ways. First, and most controversially, is the use of "objective criteria" which some commentators (e.g. Nezu (1993)) have likened to targets or VIEs. In matter of fact, the Framework agreement states that "assessment will be based on sets of objective criteria, either qualitative or quantitative or both as appropriate, which will be established using relevant information and/or data that both Governments will evaluate." In other words, the two governments are to establish agreed upon indicators of progress. The argument in favor of the benchmark approach is that by establishing objective criteria progress can be independently verified allowing negotiators to agree on areas where problems have successfully been resolved

${ }^{40}$ Contrary to the mistaken impression of some commentators, the Framework does not include quantitative targets for the external balances of either Japan or the United States, although Japan does commit itself to "a highly significant decrease in its current account surplus".

41 Topics under the government procurement basket include sector-specific issues such as Japanese procurement practices in computers, supercomputers, satellites, medical technology, and telecommunications, as well as overall central government and sub-national government policies in both countries. The regulatory reform basket includes issues of policies and practices relating to financial services, insurance, competition policy, distribution, and US export competitiveness. The other major sectors basket involves autos and parts. The economic harmonization basket includes foreign direct investment, intellectual property rights, access to technology, and long-term buyer-supplier relationships. The implementation basket is concerned with implementation of existing agreements between the two countries (including SII). 
and to focus on areas where progress has been lacking. The main criticism of the approach (other than it detracts from the multilateral system) is that it could degenerate into a system of discriminatory VIEs. In fact, there is no evidence that this has occurred. Indeed, the agreement explicitly states that the US and Japan are committed to the multilateral system, and that "benefits under this Framework will be on a Most Favored Nation basis."

The other innovation of the Framework talks is that explicitly incorporates biannual meetings of the Heads of Government. The importance of this is that it dramatically raises the political profile of the process and will in all likelihood significantly increase the pressure on policymakers to make steady progress on resolving outstanding issues. 


\section{References}

Advisory Committee for Trade Policy and Negotiations (ACTPN). 1993. "Major Findings and Policy Recommendations on U.S.-Japan Trade Policy," January. Washington.

American Chamber of Commerce in Japan. 1991. Trade and Investment in Japan: The Current Environment. Tokyo. June.

Aoki, Masahiko. 1987. "The Japanese Firm in Transition," in Kozo Yamamura and Yasukichi Yasuba eds. The Political Economy of Japan, Volume 1: The Domestic Transformation, Stanford: Stanford University Press.

. 1991. "The Japanese Firm as a System: Survey and Research Agenda," paper presented at the Japan Economic Seminar, New York, November 16.

Ariga, Kenn, Yasushi Ohkusa, and Hisashi Namikawa. 1991. "The Japanese Distribution System," Ricerche Economiche, XLV 2-3: 185-230.

Balassa, Bela and Marcus Noland. 1988. Japan in the World Economy. Washington: Institute for International Economics.

Bergsten, C. Fred and William R. Cline. 1985. "The United States-Japan Economic Problem," Policy Analyses in International Economics 13, Washington: Institute for International Economics.

, and Marcus Noland. 1993. Reconcilable Differences? Washington: Institute for International Economics.

Bhagwati, Jagdish. 1988. Protectionism. Cambridge: MIT Press.

Borrus Michael, Tyson, Laura D'Andrea, and John Zysman. 1986. "Creating Advantage: How Government Policies Shape International Trade in the Semiconductor Industry," in Paul R. Krugman editor, Strategic Trade Policy and the New International Economics, pp. 91114, Cambridge: MIT Press.

Cheng, Leonard K. 1993. "Are Distributional Costs Equivalent to Tariff Barriers?," unpublished paper, Department of Economics, Hong Kong University of Science and Technology, March.

, and Mordechai E. Kreinin. 1991. "Supplier Preference and Dumping: An Analysis of Japanese Corporate Groups," December, Michigan State University, mimeo.

Cline, William R. 1990. "Japan's Trade Policies," Institute for International Economics, Washington, May, mimeo. 
Dinopolous, Elias and Mordechai Kreinin. 1990. "An Analysis of Import Expansion Policies," Economic Inquiry, XXVIII 99-108.

Dornbusch, Rudiger. 1992. "US-Japan Relations at the Cross Roads," unpublished paper, Massachusetts Institute of Technology.

Economic Planning Agency of Japan. 1989. "Commodity Price Report," Tokyo.

Encarnation, Dennis J. 1992. Rivals Beyond Trade. Ithaca: Cornell University Press.

Flath, David. 1989. "Vertical Restraints in Japan," Japan and the World Economy 1:2 187-203.

Fung, K.C. 1991. "Characteristics of Japanese Industrial Groups and Their Potential Impact on U.S.-Japan Trade," in Robert Baldwin editor Empirical Studies of Commercial Policy, Chicago: University of Chicago Press. 137-168.

GATT. 1990. Trade Policy Review Japan. Geneva: GATT.

Gerlach, Michael. 1989. "Keiretsu Organization in the Japanese Economy," in Chalmers Johnson, Laura D'Andrea Tyson, and John Zysman, editors Politics and Productivity, Cambridge: Ballinger.

. 1992. Alliance Capitalism. Berkeley: University of California Press.

Goto, Akira and Ryuhei Wakasugi. 1986. "Technology Policy," in Ryutaro Komiya, Masahiro Okuno, and Kotaro Suzumura, editors, Industrial Policy of Japan, pp. 183-204. San Diego: Academic Press.

Goto, Fumihiro. 1990. "Is the Japanese Market Really Closed?," Research Institute of International Trade and Industry, mimeo, Tokyo, Japan.

Harrigan, James. 1993a. "OECD Imports and Trade Barriers in 1983," Journal of International Economics, 35:1/2 91-112.

. 1993b. "The Volume of Trade in Differentiated Intermediate Goods: Theory and Evidence," mimeo, University of Pittsburgh.

Ito, Takatoshi and Masayoshi Maruyama. 1991. "Is the Japanese Distribution System Really Inefficient?," in Paul R. Krugman editor, Trade with Japan, Chicago: University of Chicago Press.

Itoh, Motoshige. 1991. "The Japanese Distribution System and Access to the Japanese Market," in Paul R. Krugman editor, Trade with Japan, Chicago: University of Chicago Press.

Komiya, Ryutaro and Motoshige Itoh. 1988. "Japan's International Trade and Trade Policy, 1955-1984," in Takashi Inoguchi and Daniel I. Okimoto, editors The Political Economy 
of Japan, Volume 2 - The Changing International Context. Stanford: Stanford University Press.

Kreinin, Mordechai E. 1988. "How Closed Is Japan's Market?," World Economy, 7: 529-41.

Krugman, Paul R. "Targeted Industrial Policies: Theory and Evidence," in Dominick Salvatore ed. The New Protectionsist Threat to World Welfare, Amsterdam: North-Holland.

Laird, Sam and Alexander Yeats. 1990. Quantitative Methods for Trade Barrier Analysis. Houndsmill: Macmillan.

Lawrence, Robert Z. 1987. "Imports to Japan: Closed Markets or Closed Minds?," Brookings Papers on Economic Activity, 1987 2: 517-54.

. 1991a. "How Open Is Japan?," in Paul R. Krugman editor, Trade With Japan. Chicago: University of Chicago Press. 9-50.

. 1991b. "Efficient or Exclusionist? The Import Behavior of Japanese Corporate Groups," Brookings Papers on Economic Activity, 1991 1: 311-341.

. 1993. "Japan's Different Trade Regime" Journal of Economic Perspectives, 7:3 3-19.

Leamer, Edward E. 1991. "Empirical Studies of Trade Issues," in Ronald Jones and Anne Krueger, eds., Political Economy of International Trade: Essays in Honor of Robert E. Baldwin. Cambridge, MA: Basil Blackwell.

Lee, Hiro. 1989. "Quantitative Assessments of Japanese Industrial Policies During the 1960s," University of California at Irvine, October, processed.

Lincoln, Edward J. 1990. Japan's Unequal Trade, Washington: Brookings Institution.

Loopesko, Bonnie E. and Robert A. Johnson. 1987. "Realignment of the Yen-Dollar Exchange Rate: Aspects of the Adjustment Process in Japan," International Finance Discussion Paper 311. International Finance Division, Board of Governors of the Federal Reserve System, Washington.

Marston, Richard C. 1991. "Price Behavior in Japanese and U.S. Manufacturing," in Paul R. Krugman editor, Trade with Japan, Chicago: University of Chicago Press.

Mason, Mark. 1992. American Multinationals and Japan. Cambridge: Council on East Asian Studies Harvard University.

Ministry of International Trade and Industry. 1993. "Report on the Unfair Trade Policies by Major Trading Partners," Tokyo: MITI (mimeographed May 11).

Morgan, James C. and J. Jeffrey Morgan. 1991. Cracking the Japanese Market. New York: 
Free Press.

Nezu, Risaburo. 1993. "An Ill-advised Way to Manage Trade," Financial Times, 1 September.

Nishimura, Kiyohiko G. 1991. "The Distribution System of Japan and the United States: A Comparative Study from the Viewpoint of Consumers," paper presented to the Japan Economic Seminar, New York, November 16.

Noland, Marcus. 1990. "Prospective Changes in Japan's Trade Pattern," Japan and The World Economy 2: 211-38.

. 1992a. "Public Policies, Private Preferences, and Japan's Trade Pattern," January, Institute for International Economics, processed.

. 1992b. "Why Are Prices in Japan So High?," May, Institute for International Economics, processed.

. 1993. "The Impact of Industrial Policy on Japan's Trade Specialization," $\underline{\text { Review of }}$ Economics and Statistics, LXXV 2 241-248.

Petri, Peter A. 1991. "Japanese Trade in Transition: Hypotheses and Recent Evidence," in Paul R. Krugman editor, Trade With Japan. Chicago: University of Chicago Press. 51-84.

Rosovsky, Henry. 1985. "Trade, Japan, and the Year 2000," New York Times, 6 September.

Sato, Kazuo. 1990. "The Paradox of Japan's Distribution System," paper presented to the Japan Economic Seminar, New York, September 22.

Saxonhouse, Gary R. 1983. "The Micro- and Macro-Economics of Foreign Sales to Japan," in William R. Cline editor, Trade Policies in the 1980s. Washington: Institute for International Economics. 259-304.

- 1989. "Differentiated Products, Economies of Scale, and Access to the Japanese Market," in Robert C. Feenstra editor, Trade Policies and International Competitiveness, National Bureau of Economic Research, Cambridge.

. 1992. "Trading blocs, Pacific Trade, and the Pricing Strategies of East Asian Firms," in Jeffrey A. Frankel and Miles Kahler eds., Regionalism and Rivalry: Japan and the US in Pacific Trade. Chicago: University of Chicago Press (forthcoming).

. 1993. "Economic Growth and Trade Relations: Japanese Performance in Long-Term Perspective," in Takatoshi Ito and Anne O. Krueger editors, Trade and Protectionism, Chicago: University of Chicago Press, 149-79.

Scott, Bruce. 1987. "U.S. Competitveness in the World Economy: An Update," paper presented at the Workshop on Competitiveness, Harvard Business School, 12-18 July. 
Summers, Robert and Alan Heston. 1991. "The Penn World Table (Mark 5): An Expanded Set of International Comparisons, 1950-1988, " Quarterly Journal of Economics, 106 2: 32768.

Torii, Akio and Richard E. Caves. 1992. "Technical Efficiency in Japanese and U.S. Manufacturing Industries" in Richard E. Caves editor, Industrial Efficiency in Six Nations, Cambridge: MIT Press, pp. 425-458.

Union Bank of Switzerland, 1991. Prices and Earnings Around the Globe, Zurich.

United States Department of Commerce, 1989. The Joint DOC/MITI Price Survey: Methodology and Results, Washington, December.

. 1991. "Results of the 1991 DOC/MITI Price Survey", U.S. Department of Commerce News, ITA 91-32, May 20.

. 1993. Foreign Direct Investment in the United States, Washington, June.

Womack, James P., Daniel T. Jones, and Daniel Roos. 1990. The Machine That Changed the World. New York: Harper. 
Table 1 Selected trade indicators for six industrialized countries ${ }^{2}$

\begin{tabular}{|c|c|c|c|c|c|c|}
\hline Indicator & Japan & United States & Germany & Great Britain & France & Italy \\
\hline $\begin{array}{l}\text { Import share of } \\
\text { domestic consumption } \\
\text { of manufactures, } 1990 \\
\text { (percentages) }\end{array}$ & 5.9 & 15.3 & 15.4 & 17.7 & 13.7 & 12.6 \\
\hline $\begin{array}{l}\text { Intraindustry trade } \\
\text { index, } 1990\end{array}$ & 0.58 & 0.83 & 0.73 & 0.79 & 0.77 & 0.67 \\
\hline $\begin{array}{l}\text { Foreign firms' share } \\
\text { of domestic sales, } 1986 \\
\text { (percentages) }\end{array}$ & 1 & 10 & 18 & 20 & 27 & n.a. \\
\hline
\end{tabular}

n.a. = not available

a. intra-EC trade has been purged from the intraindustry trade and import share calculations.

Sources: Intraindustry trade indices calculated from United Nations World Commodity Trade Statistics; import shares calculated from World Bank, World Development Report; foreign firms share of sales, Julius and Thomsen (1988). 


\section{TABLE 2}

Intra-firm Trade as a Share of US Bilateral Trade

\begin{tabular}{|c|c|}
\hline US Exports & \\
\hline
\end{tabular}

\section{Europe}

Foreign Affiliates to/from Foreign Parents

US Affiliates to/from US Parents

of which, majority-owned affiliate

$\underline{\text { Japan }}$

Foreign Affiliates to/from Foreign Parents

US Affiliates to/from US Parents

of which, majority-owned affiliate
11.6

32.8

58.4

46.9

66.1

81.6

13.6

19.8

8.9

11.8

9.7

15.7

1.8

2.1

Note: "Foreign affiliate" is a firm operating in the US which is foreign-owned. "US affiliate" is a non-bank firm operating abroad which is owned by a US firm. The figures shown in the table are the percentage of US merchandise exports/imports to/form Europe and Japan which is accounted for by intra-firm trade. The US affiliates figures include a small amount of trade in services (less than $\$ 500$ million for both exports and imports).

Source: Department of Commerce, Foreign Direct Investment in the United States: An Update, June 1993. 
Table 3 Alternative estimates of potential increases in Japanese manufactures imports under complete removal of trade barriers

\begin{tabular}{llc}
\hline study & Sample period & $\begin{array}{c}\text { Potential increase } \\
\text { (percentages) }\end{array}$ \\
\hline $\begin{array}{l}\text { Bergsten and } \\
\text { Cline (1987) }\end{array}$ & 1985 & $45.4-24.4$ \\
Lawrence $(1987)$ & 1980 & 41.3 \\
Saxonhouse (1989) & 1979 & 7.2 \\
Petri (1991) & 1985 & 100.0 \\
Lawrence (1991a)c & 1985 & $76.0-54.3$ \\
Noland (1992C) & 1991 & $37.7-21.8$ \\
Saxonhouse $(1993)^{d}$ & 1983 & 7.7
\end{tabular}

a. Figures are percentage increases in imports from all sources except where noted otherwise.

b. Figure refers to US-Japan bilateral trade only. Derived from table 3.9 of the study.

c. Derived by applying general equilibrium offset factors of 0.5 (taken from Petri 1991) and 0.7 (taken from Lawrence 1987) to the initial increase of 108.5 percent.

d. Figures refer to all trade, not just manufactures and are not directly comparable to the others in the table. 
Table 4 Apparent and potential gains to liberalization in Japan (millions of dollars)

\begin{tabular}{lrlr}
$\begin{array}{l}\text { Apparent gains from liberalizations } \\
\text { implemented to date }\end{array}$ & $\begin{array}{l}\text { Potential gains from } \\
\text { future liberalizations }\end{array}$ \\
\hline Cigarettes & 1,200 & Computers $^{\mathrm{a}}$ & 1,075 \\
Beef & 500 & Fuels & 789 \\
Semiconductors & $\mathbf{1}$ & Wood products & 750 \\
Citrus & 100 & Retailing & 150 \\
Fiber optics & 33 & Supercomputers & 30 \\
\hline
\end{tabular}

a. Does not include an estimated $\$ 1$ billion in foreign-sourced products.

b. Does not include an estimated $\$ 715 \mathrm{million}$ in foreign-sourced products.

c. Includes gains attributable to Toys'R'Us only. 